NyS 45 


\section{NyS 45}

NYDANSKE SPROGSTUDIER

(C) NyS og artiklernes forfattere, 2013

\section{Redaktion:}

Tanya Karoli Christensen, Jan Heegård, Torben Juel Jensen, Janus Mortensen, Nicolai Pharao, Marianne Rathje, Jørgen Schack, Jann Scheuer

Oplysninger om abonnement og indsendelse af bidrag findes bagest i nummeret

Udgives i samarbejde med

Dansk Sprognævn

H. C. Andersens Boulevard 2

1553 København V

Tryk: Frederiksberg Bogtrykkeri A/S

ISSN 0106-8040

ISBN 978-87-89410-54-8

Printed in Denmark, 2013 


\section{Indhold}

$\begin{array}{ll}\text { Forord } & 7\end{array}$

KATHRINE THISTED PETERSEN

Lokalt regionalsprog eller regionalt rigssprog?

- en undersøgelse af Århus-dansk

JØRGEN SCHACK

Dig og mig og vi to. Synspunkter på kasus i moderne dansk

IB ULBÆK

Andenordenskohærens

SIMON BORCHMANN

Rammesætningen som typificeret handling i nyhedsanalysen

ANITA ÅGERUP JERVELUND OG JØRGEN NØRBY JENSEN

Replik til Kirstens Rasks anmeldelse af RO 2012 (bragt i NyS 44)

ABSTRACTS IN ENGLISH 